\title{
STUDI PERBANDINGAN SEJARAH DIPLOMASI ISLAM DAN BARAT
}

\author{
Oleh : Imam Taufik Alkhotob \\ STID Mohammad Natsir \\ imamtaufik@stidnatsir.ac.id
}

\begin{abstract}
Abstrak
The study of the history of diplomacy between the West and Islam is interesting to compare. Considering that the theory and science of relations between countries currently rely a lot on these two great civilizations; Islam and the West. Each influence each other and sometimes cannot be reconciled. The character of the West is more inclined to make diplomacy a tool to achieve the goals of the State by means of trickery and intrigue. So it seems very negative. Meanwhile, in the history of Islam as put by the Prophet Muhammad sallallhu 'alaihi wasallam, it is far from that bad stigma. Therefore, the conclusions of this paper are; Islam offers the power of diplomacy on the basis of equality between races, tribes and nations. Safeguard the lives, property and honor of diplomats. Keep safe between the strong and the weak. Keeping the diplomacy process away from fraud, trickery and violence. All of this shows that the Islamic conception of relations between States, between power in one area and another, is running in a modern and civilized manner.
\end{abstract}

Keywords: Diplomacy, Sifarah, History, diplomat

\section{A. LATAR BELAKANG}

Sejarah diplomasi dalam dunia politik internasional memang menarik untuk dibincangkan. Karena sejarah telah menginformasikan bahwa terdapat catatan buruk yang menyebutkan bahwa diplomasi adalah soal kelihaian dalam berbicara yang mengandung unsur kelicikan dan kebohongan. Prof. Dr. Tulus Warsito menyebutkan adanya Adagium klasik yang menyatakan bahwa para diplomat ditugaskan untuk berbohong untuk mencapai 
kepentingan nasional sebuah Negara. ${ }^{1}$ Hal itu terus berkembang di dunia Barat modern meskipun konvensi Wina 1961 tentang diplomasi internasional telah menetapkan undangundang internasional yang disepakati bersama.

Dalam sejarah politik demokrasi di Barat, bahkan setelah datangnya Islam, Barat masih belum juga mampu menentukan instrumen manakah yang paling efektif dalam diplomasi Apakah kelicikan ataukah ketulusan hati. bahkan para diplomat di zaman modern ini masih saja memberikan cara-cara menipu dalam diplomasi. Dr. Afzal Iqbal salah seorang diplomat muslim asal Pakistan yang tergerak untuk menghidupkan kembali pandangan dunia tentang diplomasi Islam dalam bukunya yang terkenal Diplomacy in Early Islam $^{2}$ banyak memberikan perbandingan tajam antara Barat dan Islam. Dalam tulisannya Dr. Afdzal mencatat tindakan diplomasi yang buruk yang dilakukan oleh Szillasy dalam beberapa situasi hingga tahun 1716 dimana Monsiour De Callierers Menerbitkan sebuah tulisan yang menggugat cara-cara diplomasi dengan wajah menipu. Sejarah diplomasi Eropa tampaknya mengajarkan penipuan yang demikian sebagaimana diungkap De Callierers, sehingga dia merasa perlu untuk meluruskannya. Baru pada abad ke-19 dunia Barat tidak membenarkan perbuatan bermuka dua dalam diplomasi. ${ }^{3}$

Sorotan diplomat muslim seperti Dr. Afzal menarik untuk dicermati. Selain selaku praktisi langsung di lapangan yang mengetahui seluk beluk diplomasi, beliau juga merasa terpanggil untuk mengungkapkan seperti apa wajah Islam dalam sejarah diplomasinya. Temuan Afzal menyebutkan bahwa diplomasi Islam adalah diplomasi yang memeliki keunggulan dibandingkan dengan diplomasi Barat. Beliau juga memaparkan sejumlah datadata sejarah yang mendukung hal tersebut. Dari paparan ini, penulis memandang penting untuk menelusuri kembali khazanah Islam periode awal terkait diplomasi ini. Dengan tujuan

\footnotetext{
${ }^{1}$ Tulus Warsito dan Surwandono, Jurnal Tauqifiyah, DIPLOMASI BERSIH” DALAM PERSPEKTIF ISLAM, Vol. 16, No. 2, Desember 2015, hal. 146

${ }^{2}$ Buku diplomasi Islam karya Dr. Afzal Iqbal berjudul Diplomacy in Islam pertama kali diterbitkan di Institut of Islamic culture lahore pada tahun 1961 saat itu penulis adalah seorang diplomat muda yang menjabat sebagai sekretaris 1 di sebuah jutaan. karya ini mendapatkan sambutan yang demikian hangat dari kalangan pemikir dan diplomat kemudian edisi kedua diterbitkan 5 tahun kemudian 1966 buku ini juga telah memberi dampak positif pada mahasiswa non muslim yang menyadari pentingnya konsep diplomasi. edisi ketiga diterbitkan tahun 1974 di Amerika yang menurut Profesor Arnold toynbee ilmu tentang Islam kultur dan sejarahnya sangat minim di sana edisi ke-empat terbit pada tahun 1976 di lahore kemudian disusul dengan edisi berikutnya tahun 1984 di New Delhi.
}

${ }^{3}$ Afzal Iqbal, Diplomasi Islam, Jakarta: Pustaka Al Kautsar: 2007, hal. 98-99 
untuk memberikan perbandingan seperti apa konsep dasar Islam terkait dengan diplomasi, yang dapat dirunut dari sejarahnya. Untuk itu, pertanyaan penelitian yang diajukan dalam makalah ini adalah; Bagaimana sejarah diplomasi dalam Islam dan seperti apa nilai-nilai yang terkandung di dalamnya. Hal itu sebagai perbandingan kita ketika melihat diplomasi modern hari ini maupun diplomasi Barat dalam sejarahnya.

\section{B. KAJIAN DAN DISKUSI}

\section{Definisi dan Sejarah Diplomasi}

Sebagai disiplin ilmu modern yang berkembang, kajian diplomasi masuk kedalam ilmu politik hubungan internasional. Setelah berkembang ke zaman modern maka definisi diplomasi terus berkembang dan mengalami perbaikan. Dr. Umar Suryadi Bakry dalam bukunya Dasar -dasar Hubungan Internasional mencatat bahwa Secara leksikal diplomasi (diplomacy) didefinisikan sebagai keterampilan (skill) dalam berhubungan dengan orang lain tanpa menyebabkan perasaan buruk. Atau seni (art) yang berhubungan dengan orang-orang dengan cara yang secara sensitive dan efektif, atau dapat pula diartikans ebagai ilmu (science) melakukan negosiasi dengan pihak lain. ${ }^{4}$

Oxford Dictionary mendefinisikan the activity of managing relations between different countries; diplomasi sebagai manajemen hubungan internasional dengan cara negosiasi. Dapat pula diartikan sebagai provesi, aktifitas, atau keterampilan mengelola hubungan internasional, biasanya melalui perwakilan suatu Negara di luar negeri. ${ }^{5}$ Ernest Satow juga mendefinisikan diplomasi sebagai penerapan dari kecerdasan dan kebijaksanaan untuk melakukan hubungan resmi antara pemerintah dari Negara-egara berdaulat. Kadang-kadang juga hubungan Negara Negara berdaulat dengan negar vassal. ${ }^{6}$

Sebagai sebuah fenomena social, diplomasi telah berkembang dan berevolusi dari satu sejarah peradaban ke peradaban lainnya. Menurut literature Barat Modern, diplomasi sudah ada sejak zaman Yunani, China, Bizantium, dan Romawi. Afzal Iqbal kembali mencatat bahwa Sejarah Diplomasi telah mempunyai kesan yang negatif. Diplomasi difahami sebagai

${ }^{4}$ Umar Suryadi Bakri, Dasar-dasar Hubungan Internasional, Depok: Penerbit Kencana, 2017, hlm.

${ }^{5}$ https://www.oxfordlearnersdictionaries.com/definition/english/diplomacy?q=diplomacy

${ }^{6}$ Ernest Satow, A Guide to Diplomacy Praktic, The Library of California, hal. 1 
tindakan yang dibangun tanpa moralitas. Baik nilai-nilai moralitas umum apalagi jika disandingkan dengan nilai dalam Islam. Bahkan para diplomat Barat saat ini tentu akan merasa malu jika Hermes terpilih sebagai Dewa yang menduduki profesi sebagai diplomat. Dalam mitologi Yunani Hermes dikenal sebagai Dewa diplomasi yang diasosiasikan dengan kegantengan dan kelicikan penipuan dan seni rendahan yang kemudian dia memberikannya kepada Pandora seorang wanita pertama yang merusak dengan menggunakan kelicikan dan kelicinan otaknya. $^{7}$

Pada masa pemerintahan dixanthium cara-cara negosiasi dengan keculasan dan korupsi sangat terkenal. Catatan buruk kepausan Chanceries Di abad pertengahan juga mewarisi cara-cara diplomasi yang sangat merusak. hal itu Diteruskan oleh diplomat seperti Florentina di zaman Renaissance seperti Dante, Petrach, Boccaccio dan murid-muridnya yang datang setelah itu seperti Guicciardini, Dan machiavelli. Seorang duta besar Inggris Sir Henry Wotton pada suatu saat dengan sinis menyatakan; "duta besar adalah seseorang yang menipu di luar negeri demi kepentingan negerinya sendiri." 8

Literatur Hukum Internasional menyebuktan bahwa Kongres Wina 1815 adalah asal mula diplomasi yang terorganisir. Menurut Harold Nicolson ${ }^{9}$ Dalam kongres ini diantarnya disepakati berbagai prosedur, regulasi, dan representasi yang berkenaan dengan diplomasi antar Negara. Salah satu kesepakatan tersebut diantaranya menyangkut empat katagori representative (perwakilan diplomasi) yaitu; Duta besar atau utusan kepausan, Utusan luar biasa dan menteri-menteri berkuasa penuh, Ministry resident dan Kuasa usaha atau charge d'affairs. Kemudian hampir semua aspek tentang praktik diplomatic ditandatangani oleh 81 negara pada Konferensi Wina 1961 tentang hubungan dan kekebalan diplomatic.

\section{Diplomasi dalam Islam; Tinjauan Sejarah}

Kata diplomasi memang tidak dikenal dalam sejarah Islam. Diplomasi sendiri merupakan bahasa yang disadur dari bahasa Greek Yunani yaitu; diploma atau dalam kata kerjanya diplon. Kata ini merujuk kepada arti kertas atau melipat. Adapun di dalam Islam istilah yang biasa digunakan untuk memaknai kata diplomasi adalah; sifarah (kedutaan).

\footnotetext{
${ }^{7}$ Afzal Iqbal, Diplomasi Islam, hal. xxii

${ }^{8}$ Ibid.,

${ }^{9}$ Harold Nocolson, Diplomacy, London: Oxford University Toronto, 1939, hlm. 14
} 
Kata ini telah dikenal oleh masyarakat Makkah sebelum Islam datang. Tugas ini di jabar oleh Bani adi.

Dalam Kepemimpinan kota Makkah sebelum kenabian, maka Bani Adi adalah yang diberikan tugas untuk urusan hubungan antar suku dan raja-raja yang dikenal dengan istilah as sifarah (urusan kedutaan). Pada masa Rasulullah tinggal di Makkah, Umar Ibn Khattab dari suku Bani Adi diberikan tugas untuk hal tersebut. ${ }^{10}$ Bani Adi juga diberikan tugas sebagai utusan untuk menentukan sengketa perselisihan di dalam suku-suku di kota Makkah. Bani Adi memiliki keutamaan tersendiri dalam hal ini, dimana kakek-kakek Umar Ibn Khattab seperti Nufail bin Abdil Uzza juga sorang hakim yang orang-orang Quraisy berhukum pada dirinya, dan hal itu diwariskan kepada keluarganya. ${ }^{11}$

Kata diplomasi dikemudian hari diserap menjadi istilah dalam bahasa Arab yaitu; ad diblomasiyyah. Tentu saja kata ad diplomasiyyah belum dikenal pada masa awal Islam. Atinya kata tersebut termasuk ke dalam kamus bahasa Arab pada masa belakangan. Adapun pada masa Rasulullah terdapat beberapa istilah yang digunakan yaitu as sifarah, ar rasul, dan al barid yang juga bermakna; utusan, duta, atau diplomat dan diplomasi. Dalam kontek hubungan diplomasi antar suku dan negara, maka Rasulullah melakukan pengutusan pengutusan kepada suku-suku, raja-raja yang disertai dengan pengiriman surat untuk memperkenalkan Islam dan menyerukan kepadanya. Maka jabatan sifarah adalah sebuah administrative yang sangat penting yang mendapat perhatian dari Negara.

Surat-surat perjanjian ini meliputi perjanjian Nabi dengan Yahudi dan Nasrani, perjanjian damai antara Nabi dan beberapa suku, surat jaminan keamanan, surat seruan da'wah kepada para kepala suku, raja, dan para pemimpin dan lain-lain. Semua data tersebut membuat kita mampu menegaksan bahwa sifarat (diplomasi) dan surat-surat Rasulullah menggambarkan sebuah aktivitas diplomasi dan hubungan internasional yang sangat menakjubkan. ${ }^{12}$ Surat-surat ini memuat kalimat-kalimat yang jika dicermati memiliki bahasa

${ }^{10}$ Sami bin Abdullah Al Malghuts, Athlas At Tarikhi li as Sirah An Nabawiyah, Riyadh: Maktabah Al Ubaikan, 2004, hal. 94

${ }^{11}$ Ali Muhammad Ashalabi, Sirah Amirul Mukminin Umar bin Khattab; Syakhsiyatuhu wa 'Ashruhu, Mesir: Mu'assasah Iqra: 2005, hal. 16

${ }^{12}$ Hafidz Ahmad 'Ajjaj al Karmi dalam bukunya Al Idarah fi 'Ashri al Rasul, Mesir: Dar As salam IIIT, 2000, hal. 128 
yang tinggi. Sifatnya adalah jelas, padat isi, lugas, penuh kejujuran dan wibawa, serta jauh dari tipuan muslihat.

Menurut Dr. Hafidz Ahmad ‘Ajjaj al Karmi dalam bukunya Al Idarahfi 'Ashri al Rasul mencatat sejumlah sumber sejarah para ulama juga telah menyebutkan sejumlah nama-nama duta atau diplomat yang pernah diutus oleh Nabi kepad para raja, dilengkapi dengan surat yang berisi seruan terhadap meraka kepada Islam diantaranya; ${ }^{13}$

1. Dihyah bin Khalifah al Kalbi yang diutus kepada Kaisar Raja romawi ${ }^{14}$

2. Abdullah bin Hudzafah As Sahmi yang diutus kepada Raja Persia. ${ }^{15}$

3. Amr bin Umayyah ad Dhamri yang diutus kepada Raja Najasyi. ${ }^{16}$

4. Hatib bin Abi Balta'ah yang diutus kepada Raja Al Muqauqis di Mesir ${ }^{17}$

5. Amr bin Al Ash kepada penguasa Oman Jifar dan Ayyad.

6. Sulait bin Amr dikirim kepada Tsumamah bin Utsal dan Haudzah bin Ali. Dua orang raja Yamamah.

7. Al A'la Al Hadrami, diutus kepada Al Munzir bin Sawa Raja Bahrain

8. Suja' bin Wahab al Asadi diutus kepada Al Harits bin Abdi Kalal Al Himyari, seorang Raja Takhum di Syam. ${ }^{18}$

Pada kesempatan lainnya Rasulullah al Amin juga mengirim sejumlah duta (sifarah) kepada sejumlah suku-suku. Nabi mengutus Zhabyan bin Mursyid ad Dausi kepada Bani Bakar bin Wa'il, Jarir bin Abdillah Al Bajali kepada Al Kala' bin Nakur, juga Amr bin Umayyah ad Dhamri kepada Musailamah al Kadzab dan lain-lain. Pengiriman utusan itu terjadi pada akhir akhir tahun ke enam dan awal tahun ke tujuh pasca perdamaian Hudaibiyyah. Hasil terbesar dari surat-surat yang dikirim oleh Rasulullah ini membentuk opini di dunia internasional bahwa Islam adalah agama yang datang kepada seluruh bangsa manusia.

13 Ibid.,

${ }^{14}$ Muhammad bin Jarir bin Katsir At Thabari, Tarikh Ar Rusul wa Al Muluk, Beirut: Dar At Turats, 1387, Jillid 2, hal. 646

${ }^{15}$ Abdu Syafi Muhammad Abdul Latif, As Sirah An Nabawiyah wa At Tarikh Al Islâmiy, Mesir: Dar As Salam, 1428, hal. 155

${ }^{16}$ At Thabari, Tarikh, Jilid 2, hal. 562

${ }^{17}$ Abu Amru Khalifah bin Khayyat, Târikh Khalifah bin Khayyath, Tahqiq: Dr. Akram Dhiya' Al Umari, Beirut: Dar Al Qalam, 1397, hal. 79

${ }^{18}$ Ibnu Saad berpendapat bahwa sebenarnya yang dikirim kepada raja Takhum di Syam ini adalah sahabat lainnya yaitu Ayyas bin Abi Rabi’ah al Makhzumi (Ibnu Sa'ad, Thabaqat, Jilid 1, hal. 282) 
Dengan demikian diplomasi Islam telah dilakukan dan diperkuat kedudukannya sejak masa Rasulullah. Rasulullah sebagai pemimpin Negara telah menunjukkan aktifitas diplomasi yang tinggi dan penuh dengan keteladanan. Politik Islam yang dibangun oleh beliau menunjukkan bahwa Islam mampu membangun paradigma baru dalam hal hubungan antar bangsa maupun Negara pada masanya. Kekuatan Islam yang dibawa oleh Rasulullah bahkan mampu merubah situasi politik di dunia. Kiblat peradaban yang saat itu selalu tertuju pada peradaban Romawi dan Persia kini memiliki alternativ. Peradaban Romawi dan Persia yang menjadi rujukan dalam berbagai bidang kehidupan manusia, ternyata tidak mampu bertahan dengan gerakan Islam yang timbul secara cepat dan tidak terbendung. ${ }^{19}$

Berikut kita akan melihat beberapa aspek diplomasi yang kita dapati pada masa Rasulullah;

\section{A. Aspek Hubungan antar Bangsa dan Negara}

Afzal Iqbal memaparkan bahwa Dengan lahirnya Islam kita melihat lahirnya suatu perubahan secara revolusioner yang menetapkan prinsip hukum internasional dan diplomasi. Islam dengan tegas menyatakan persamaan antar manusia. Al Qur'an menyebutkan dasar itu adalam surah al-Hujurat ayat ke 13 .

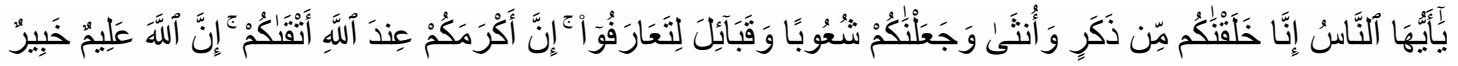
Artinya: "Hai manusia, sesungguhnya Kami menciptakan kamu dari seorang laki-laki dan seorang perempuan dan menjadikan kamu berbangsa-bangsa dan bersuku-suku supaya kamu saling kenal-mengenal. Sesungguhnya orang yang paling mulia di antara kamu di sisi Allah ialah orang yang paling takwa di antara kamu. Sesungguhnya Allah Maha Mengetahui lagi Maha Mengenal.” (QS. Al Hujarat: 13)

Islamlah yang pertama kali mengajarkan ide negara universal atas dasar persamaan diantara manusia. Dalam hukum Islam lah kita dapatkan pertama kali hak-hak musuh baik dalam keadaan perang maupun damai dijamin dalam Alquran dan hadis rasulullah. Hukum

${ }^{19}$ Romawi dan Persia bertempur lebih dari 700 tahun dengan ribuan pertempuran. Namun keduanya tindak mampu saling menundukkan. Ketika Islam datang, setelah wafatnya Rasulullah, kaum muslimin cukup dengan waktu kurang lebih 4 tahun untuk menyelesaikan dua peradaban lama itu secara sekaligus dengan puluhan pertempuran saja. 
internasional yang di bangun Islam ini selain menawarkan regulasi antar negara muslim dengan formula yang seadil-adilnya tetapi juga antara negara Islam dengan negara non Islam di seluruh dunia. Muhammad Hamidullah dalam bukunya The Muslim Conduct of State menyebutkan bahwa hukum internasional Eropa telah banyak belajar dan melihat dari kompilasi kitab-kitb yang ada di dalam hukum-hukum Islam. Tentu saja hal ini menunjukkan pengaruh besar dalam hukum Internasonal hari ini. ${ }^{20}$

Pemikiran Islam tentang ketentuan-ketentuan yang mengatur hubungan internasional baik publik internasional (Qanun ad duwali al 'am) Maupun hukum privat internasional yang bersumber dari Alquran dan teladan Rasulullah ini juga telah mempengaruhi ahli-ahli hukum internasional Eropa abad ke-17 seperti Piero Belo Victoria dan Alberico Gentili dalam merumuskan hubungan internasional. Dasar-dasar hubungan internasional ini mereka pelajari di Spanyol Andalusia ketika menjadi pusat peradaban Islam abad ke-8 sampai ke-15 dan mereka kembangkan di Eropa. Hugo Grotius tahun 1645 yang dianggap sebagai Bapak hukum internasional yang berjasa menyusun daftar peraturan hukum perang mengakui besarnya pengaruh Islam dalam penulisan hukum internasional yang termuat dalam buku berjudul De jure Belli ac Pacis. ${ }^{21}$ Bahkan menurut Muhammad Abdullah Diraz, filosof barat sekaliber John Stewart masih menyangsikan bila hubungan internasional berdasarkan persamaan itu dapat diimplementasikan di negara-negara yang menurutnya masih dalam taraf terbelakang. Pakar hukum Barat modern sebelum Perang Dunia 2 dan berdirinya PBB masih membedakan secara diskriminatif kawasan dunia menjadi tiga bagian yaitu kawasan bangsa-bangsa berperadaban yang memperoleh hak politiknya secara penuh kawasan semi peradaban ia memperoleh sebagian hak-hak politiknya dan kawasan bangsa-bangsa terbelakang yang sama sekali tidak memperoleh politik tetapi diperlukan menurut ukuran kebiasaan-kebiasaan antar bangsa. ${ }^{22}$

Paradigma hubungan antara bangsa dan Negara di dalam Islam juga dibangun berdasarkan prinsip-prinsip perdamaian, bukan peperangan sebagaimana prinsip kekuasaan imperium dan raja-raja besar sebelum datangnya Islam. Islam cenderung untuk

\footnotetext{
${ }^{20}$ Muhammad Hamidullah, The Muslim Conduct of State, Kuala Lumpur: Islamic Book Trust, 2012, hal. 65

${ }^{21}$ Ichwan Fauzi, Etika Muslim, Penerbit, Wisdom Science Sea, Hal. 79

${ }^{22}$ Ichwan Fauzi, Etika Muslim mengutip, Muhammad Abdullah Darraz, Dirosat Islamiyah fil alaqat al ijtima'iyyah wa ad dawliyyah, h. 141
} 
mengedepankan aspek perdamaian dan penegakan argument (da'wah). Peperangan adalah tindakan yang dapat diambil kemudian jika tahapan-tahapan perdamaian telah ditempuh namun tidak diterima.

Memang terdapat perbedaan pandangan para ulama Islam mengenai apa hukum asal hubungan antar Negara dalam Islam (Negar Islam vs Negara Kafir). Muhammad Habas, $A l$ Islam wa Al Diplomasiyyah; Qira'ah fi al Qim al Diplumasiyyah fî al Islâm menyebutkan bahwa para ulama berbeda pendapat kepada tiga bagian $;^{23}$

Pertama, pendapat yang menyebutkan bahwa hubungan asal antara kedua Negara ini adalah al harbu (peperangan). Hal ini sebagiamana pendapat yang disebutkan olah ulama fiqih empat mazhab dari kalangan hanafiyah, malikiyah, syafi'iyyah, dan hanabilah. Pendapat ini diikuti pula oleh para Ulama kontemporer seperti; Syaikh Abul A'la al Maududi, Sayyid Qutub, dan Syaikh Shalah Al Haidan rahimahulullah.

Kedua, pendapat yang menyebutkan bahwa hubungan asal antara Negara Islam dan Negara kafir adalah al salam (perdamaian). Peperangan hanya akan terjadi jika terjadi serangan dari pihak lain, upaya kaum kuffar dalam mengganggu agama Islam, dan sebabsebab lainnya. Hal ini sebagaimana disebutkan oleh para ulama seperti; Imam Al Auza'I, Imam Al Tsauri, Imam Ibn Taimiyyah, Imam Ibnu Qayyim dan diikuti oleh Ulama kontemporer seperti; Syaikh Wahbah Az Zuhaili, Syaikh Abu Zahrah, Syaikh Mahmud Syaltut, dan lain-lainnya.

Ketiga, pendapat yang menyebutkan bahwa hokum asalnya adalah da'wah. Yaitu da'wah yang dilakukan sesuai dengan kondisi yang terjadi di suatu daerah atau wilayah.

Pendapat yang terkuat dalam hal ini adalah pendapat kedua. Hal itu sebagaimana dasar yang diambil dalam al qur'an al karim dalam sejumlah ayat seperti;

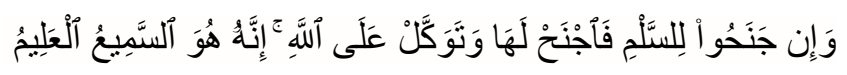

Dan jika mereka condong kepada perdamaian, maka condonglah kepadanya dan bertawakkallah kepada Allah. Sesungguhnya Dialah Yang Maha Mendengar lagi Maha Mengetahui. (QS. Al Anfal: 61)

${ }^{23}$ Muhammad Habas, Al Islam wa Al Diplomasiyyah; Qira'ah fi al Qim al Diplumasiyyah fí al Islâm, Arabiya: Aspir Printing Press, 2013, hlm. 25-24 
Juga sejumah ayat seprti termaktub dalam (QS. Al Baqarah: 208, An Nisa: 90 dan 94, Al Ankabut: 46.

\section{B. Aspek Pemilihan Utusan}

Dalam pemilihan duta, Nabi tidak pernah keluar dari konvensi dan kebiasaan yang telah berlaku pada diplomasi modern seperti; pergantian duta, keindahan postur tubuh, ketampanan wajah, dan kemampuan yang tinggi. ${ }^{24}$ Ilmu diplomasi modern mensyaratkan perhatian seorang kepada penampilan. Maka seorang diplomat memang kerap kali tampil dengan wajah dan perawakan yang ideal. Jauh sebelu itu, Nabi telah mencontohkan bagaimana seharusnya seseorang memilih duta mewakili negaranya. Dr. Sulaiman Al Ruhaili dalam kajiannya terhadap Diplomasi Daulah Islam dan Daulah Romawi Bizantium dalam kitabnya As Sifarât Al Islâmiyyah ilâ Bilad Bizantiyyah menjelaskan hal ini. Ia menegaskan bahwa pemilihan yang dilakukan oleh Rasulullah ini sangat penting karena hal pertama yang akan dilihat dalam konteks diplomasi adalah perawakan dan wajah seseorang. Hal itu karena mereka adalah representasi dari Umat Islam dan Agama yang Nabi bawa. Sebagai contoh, Nabi mengapa Nabi mengirim sahabat Dihyah al Kalbi?, sebab Dihyah adalah laki-laki yang tampan dan menarik di zamannya. Dalam riwayat disebutkan bahwa Jibril seringkali bertemu kepada Rasulullah dalam rupa yang mirip dengan Dihyah Al Kalbi. $^{25}$

Dalam kontek pengiriman duta-duta Rasulullah memberikan arahan:

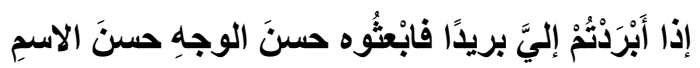

"Apabila Kalian mengirimkan duta kepadaku, maka kirimkanlah yang memiliki wajah tampan dan memiliki nama yang Indah.” (hadits Hasan, Jami’ As Shagir, no: 336)

Hal ini berlaku pula kepada sahabat-sahabat lainnya seperti Mu'adz bin Jabal, Abu Musa Al Asy'ari, Abdullah bin Hudzafah, Amr bin Al Ash dan yang lainnya. Mereka adalah para sahabat yang paling cerdas, paling tampan, paling indah tutur katanya, paling terampil

\footnotetext{
${ }^{24}$ Sulaiman Al Ruhaili, As Sifarât AL Islâmiyyah ilâ Bilad Bizantiyyah, Riyadh: Maktabah At Taubah, 1414 H, Hal. 30

${ }^{25}$ Ibnu Hajar al Atsqalani, Al Ishabah fĩ Tamayyiz Al Shahabah, Tahqiq. Syaikh Adil Ahmad Abdul Maujud, et.all, Lebanon: Dar Al Kutub al Ilmiyyah, 1995, Jilid 2, hal. 321
} 
lisannya, dan paling kuat argumentasinya. Selain itu mereka adalah orang-orang yang terkenal memiliki keilmuan yang tinggi, piawai dalam soal surat-menyurat dan bidang administrasi di tengah-tengah masyarakat wakti itu. ${ }^{26}$

Syarat lain dalam pengiriman duta diplomasi adalah kefasihan dalam berbicara. Hal tersebut dilakkan oleh Rasulullah dan juga para khalifah kaum muslimin setelahnya. Prof. Dr. Musa Syahhin Al Asyin, Fathul Mun'im Syarah Sahih Muslim mengutip kisah Rasulullah dimana beliau pernah mengutus sahabat Hatib bin Abi Balta'ah kepada imperium Raja Kristen Muqauqis di Mesir. Setelah sahabat Hatib menjelaskan melakukan diplomasi dan dialog kepada raja dan menyampaikan pesan-pesan Islam maka Raja Muqauqis pun merasa takjum dengan kalimat-kalimat yang disampaikan dengan penuh kewibawaan tersebut. Ketertarikan Raja Muqauqis kepada Islam tampak dari sikapnya bahkan memberikan apresiasi kepada sahabat Hatib sebagai utusan (diplomat) kala itu dengan perkataan yang masyhur; ${ }^{27}$

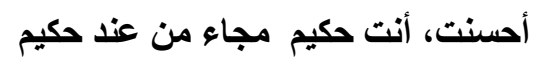

(Sungguh benar apa yang engkau katakana. Engkau adalah seseorang yang penuh hikmah dan berasal dari utusan yang juga penuh dengan hikmah.)

Dari pertemuan ini kita mengetahui bahwa Raja Muqauqis memberikan titipan hadiah untuk Rasulullah berupa sahaya Mariyah al Qibtiyah yang kemudian dinikahi oleh beliau dan kelak akan melahirkan putra yang bernama Ibrahim.

\section{Aspek Hak-hak Khusus Keamanan}

Hukum konvensional diplomasi memberikan beberapa hak khusus bagi para duta. Duta memiliki suatu hak yang disebut dengan perlindungan keamanan, atau yang disebut dengan istilah "kekebalan diplomasi." Dengan hak ini, seorang duta, istri dan anak anaknya juga seluruh staf yang membantunya diberikan jaminan kamanan penuh. ${ }^{28}$ Kekebalan diplomasi juga berbicara tentang keamanan pada kediaman tempat tinggal, diamanapun seorang diplomat bertugas. Menurut Prof. Mr. Ag. Pringgodigdo Dalam kontek hukum

${ }^{26}$ Hafidz Ahmad 'Ajjaj al Karmi, Al Idarah fi 'Ashri al Rasul, hal. 13-15

${ }^{27}$ Musa Syahhin Al Asyin, Fathul Mun’im Syarah Sahih Muslim, Mesir: Dar Al Suruq, 2002, Jilid 9, hal. 513

${ }^{28}$ Hafidz Ahmad 'Ajjaj al Karmi, Al Idarah fi 'Ashri al Rasul mengutip tulisan Al Munjid, Nudzûm Diblomasiyah, hal. 80 
internasional, kita mengenal istilah "Kekebalan Diplomatik" yaitu jaminan kemanan bagi pada diplomat dalam menjalankan tugasnya. Termasuk kediaman mereka. Mereka dilindungi dengan hak eksteteriolitas. ${ }^{29}$

Pada Pasal 27 Konvensi Wina tahun 1961 mengenai hubungan diplomatik disebutkan bahwa ${ }^{30}$

"1.The receiving State shall permit and protect free communication on the part of the mission for all official purposes. In communicating with the Government and the other missions and consulates of the sending State, wherever situated, the mission may employ all appropriate means, including diplomatic couriers and messages in code or cipher. However, the mission may install and use a wireless transmitter only with the consent of the receiving State. 2.The official correspondence of the mission shall be inviolable. Official correspondence means all correspondence relating to the mission and its functions. 3.The diplomatic bag shall not be opened or detained. 4.The packages constituting the diplomatic bag must bear visible external marks of their character and may contain only diplomatic documents or articles intended for official use."

((1) Negara penerima harus mengijinkan dan melindungi kemerdekaan berkomunikasi pada pihak misi untuk tujuan-tujuan resminya. Di dalam berkomunikasi dengan Pemerintah, misimisi dan konsulat-konsulat, dari Negara pengirim, dimanapun beradanya, misi boleh menggunakan semua sarana yang pantas, termasuk kurir diplomatik dan pesan-pesan dengan sandi atau kode. Namun demikian, misi boleh menggunakan dan memasang pemancar radio hanya dengan persetujuan dari Negara penerima. (2) Korespondensi resmi daripada misi tidak dapat diganggu gugat. Korespondensi resmi adalah semua korespondensi yang berhubungan dengan misi dan fungsi-fungsinya. (3) Tas diplomatik tidak boleh dibuka atau ditahan. (4) Paket yang ada di dalam tas diplomatik harus memperlihatkan tanda yang jelas dapat terlihat dari luar yang menunjukkan sifatnya dan hanya boleh berisi dokumendokumen diplomatik atau barang-barang yang diperuntukkan bagi kegunaan resmi daripada misi)

Pada masa Rasulullah, jaminan keamanan bagi para duta dan utusan adalah sesuatu yang mutlak harus dijaga. Beliau mengajarkan syari'at yang mulia yang dengannya umat Islam wajib memuliakan seorang duta dan memberikan jaminan keamanan kepadanya. Hal

\footnotetext{
${ }^{29}$ Mr. Ag. Pringgodigdo, Ensiklopedia Umum, Yogyakata: Penerbit Kanisius, 1973, hal. 275

${ }^{30}$ PBB, Vienna Convention on Diplomatic Relations 1961, Copy Rigt United Nation, 2005, hal. 8
} 
ini sebagaimana implementasi yang Nabi lakukan tak kala beliau menerima berbagai utusan dari suatu suku atau raja-raja. Sebagai contoh Rasulullah pernah menerima utusan dari Musailamah al Kadzab. Para utusan itu menyatakan dihadapan Rasulullah bahwa mereka bersaksi bahwa Musailamah adalah utusan Allah. Melihat hal itu Nabi tidak bersikap keras kepada mereka. Meskipun ucpan itu merupakan ucapakan kekufuran namun Nabi tidak lantas menghukumnya. Dalam hal ini Nabi bersabda;

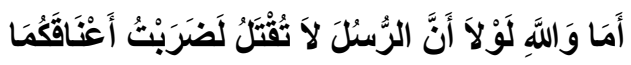

Ingatlah, demi Allah, seandainya tidak ada larangan memebunuh para duta, niscaya aku akan memenggal leher kalian berdua." (HR. Abu Dawud dan Ad Darimi) ${ }^{31}$

Menganai hadits ini Al Imam Muhammad Asyraf bin Amir bin Ali bin Hidr Al Adzim Al Abadi dalam kitabnya 'Aunul Ma'bud Syarah Sunan Abi Dâwûd mengatakan: ${ }^{32}$

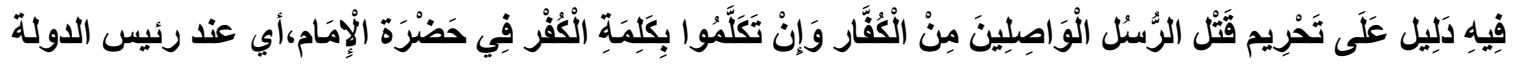
(DIdalamnya terdapat dalil tentang haramnya membunuh para utusan yang datang dari orang-orang kafir meskipun mereka berbicara dengan kalimat kekufuran di hadapan seorang pemimpin atau keapala negara)

Mengenai hal ini Al Imam Ibnu Qayyim Al Jauziyah juga menjelasakan bahwa apabila datang kepada kaum muslimin utusan (delegasi/diplomat) sementara mereka bersetatus sebagai musuh, maka dilarang untuk diserang atau dibunuh. ${ }^{33}$ Beliau berkata;

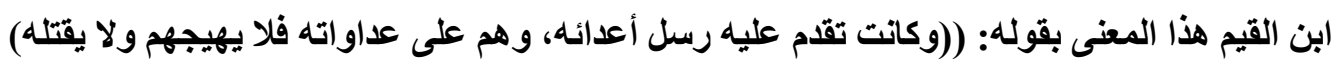

Berkaitan dengan hal ini teradapat pula hak istimewa bagi duta yang dijaga oleh Islam yaitu larangan untuk menahan duta. Hal ini merupakan bagian yang diakui dalam hukum internasional modern yang bahkan telah menjadi tradisi yang dijaga sejak datangnya Islam. Islampun meneguhkan dan memasukkannya dalam bagian penting pada syari'at kenegaraan. Beberapa referensi menyebutkan bahwa Suku Quraish pernah mengirim utusan bernama Abu Rafi' ke Madinah untuk bertemu Nabi. Sampai di Madinah, justru Abu Rafi' tertarik

${ }^{31}$ Berkata AL Hakim dalam kitab Al Mustadrak, Jilid 2, hal. 155 bahwa; "hadits ini shahih berdasarkan syarat Imam Muslim”. Demikian pula yang dinukil dalam Adz Zahabi.

${ }^{32}$ Muhammad Asyraf bin Amir bin Ali bin Hidr Al Adzim Al Abadi, 'Aunul Ma'bûd Syarah Sunan Abi Dâwûd, Beirut: Darul Kutub Al Ilmiyyah, 1415, Jilid 7, hal. 314

${ }^{33}$ Ibnu Qayyim Al Jauziyah, Zaâdul Ma'ad min Hadyi Khairil 'Ibad, Beirut: Mu'assasah Ar Risalah, 1994. Jilid 3, hal. 125 
kepada Islam dan ingin tinggal di Madinah. Meskipun keinginan Abu Rafi' begitu kuat, namun Nabi bersabda kepada Abu Rafi';

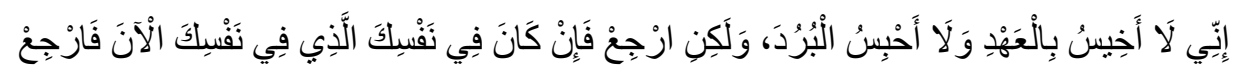

Sesungguhnya aku tidak akan mengingkari janji dan tidak akan menahan seseorang duta. Akan tetapi kembalilah kepada mereka. Jika keimanan yang ada di dalam hatimu sekarang itu benar, maka kembalilah ke Madinah."(HR. Abu Dawud, Ahmad, Ibnu Hibban dan Disahihkan oleh Syaikh Al Bani dalam As Sahihah ${ }^{34}$ )

Penahaman seorang duta akan mengakibatkan buruknya hubungan yang telah dijalin antar Negara. Hal itu bahkan akan memicu terjadinya peperangan antara kedua belah pihak.

\section{Aspek Hak Untuk Menjamin Kebebasan Beribadah}

Para duta yang datang ke negeri Islam diberikan hak untuk beribadah sesuai dengan kepercayaan yang dimilikinya. Rasulullah melarang keras mengganggu para utusan yang datang ketika mereka menjalankan ritual ibadah mereka. Inilah faktor yang mendorong penghormatan kepada pihak-pihak yang menjadi tujuan pendelegasian. Hal ini sebagaimana yang terjadi pada kisah delegasi kaum Nasrani dari Bani Najran yang melaksanakan Ibadah mereka di Masjid Nabawi. Nabi mengizinkan mereka untuk melaksanakan ibadah di Masjid karena mereka tidak menemukan tempat untuk beribadah. Fasilitas tempat ibadah yang diberikan Nabi ini bukanlah tanda persetujuan Nabi terhadap keimanan yang mereka pegang. Akan tetapi mereka semua adalah para utusan yang datang mewakili suatu kaum yang berhak untuk dijaga keamanan mereka ${ }^{35}$.

\section{E. Aspek Memulikan Para Duta}

Ketinggian prinsip moral dalam hal diplomasi ditunjukkan oleh Nabi kepada para duta dan utusan yang datang. Beliau menghormati mereka dan memberikan kesan baik dalam penerimaan. Salah satunya adalah dengan cara mengenakan pakaian yang bagus. Imam Al Bukhari meriwayatkan bahwa Nabi pernah mendapatkan hadiah dari salah seorang sahabat berupa baju yang bagus. Sahabatpun mengusulkan agar Nabi mengenakannya saat hendak

\footnotetext{
${ }^{34}$ Muhammad bin Hibban bin Ahmad bin Hibban, Sahih Ibn Hibban bi at Tartib al Hibban, Tahqiq: Syuaib al Arnauth, Beirut: Mu'assasah Ar Risalah, 1993, Jilid 11, hal. 233

${ }^{35}$ Hafidz Ahmad 'Ajjaj al Karmi, Al Idarah fi 'Ashri al Rasul, hal. 131
} 
menerima para duta dari berbagai daerah. Untuk itulah Nabi menyambut baik hal tersebut dan bahkan Nabi bersabda;

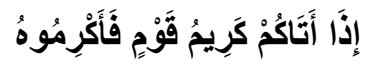

“Apabila utusan suatu kaum datang kepada kalian, maka muliakanlah ia” (HR. Ibn Hibban, dihasankan oleh Syaikh Al Bani) ${ }^{36}$

Aspek pemuliaan ini dilakukan dalam banyak hal. Nabi terkadang menghormati tamu dengan cara membentangkan selendang beliau dan menyertakan mereka dalam tempat duduk. Hal itu selain penghormatan juga merupakan cara Nabi untuk menghilangkan rasa canggung, resah, dan menghadirkan rasa nyaman karena kedekatan yang beliau lakukan. Dalam rangka penghormatan pula ahli sejarah Al Imam Ibn Sa'ad dalam kitabnya Thabqât al Kubra menginformasikan tentang adanya sebuah kediaman khusus yang oleh Nabi ditunjuk sebagai kediaman tempat menampung para utusan (duta). Ibn Sa'ad meriwayatkan bahwa Nabi menunjuk kediaman Ramlah binti al Harits an Najrani sebagai tempat peristirahatan para duta. rumah beliau ini dikenal dengan istilah Dar al Dhaifan (Rumah bagi para tamu). ${ }^{37}$ Bahkan Antropolog Islam Ibn Khaldun menyebutkan bahwa Nabi menunjukkan sikap baik dengan memberikan jamuan dan cinderamata yang dapat dibawa pulang oleh para duta. ${ }^{38}$ Bahkan dalam suatu perjalanan jauh Nabi pernah kedatangan utusan dari Heraklius saat beliau sedang berada di Tabuk $(9 \mathrm{H})$. Nabi mengatakan permintaan maaf karena sedang dalam perjalanan dengan mengatakan;

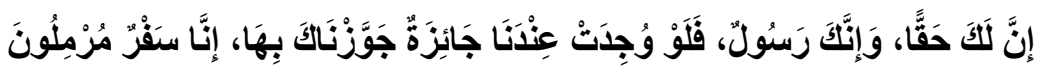

"Sesungguhnya engkau memiliki hak. Engkau adalah seorang duta. Seandainya kami ada cendera mata, tentu kami akan membekalimu dengannya. Namun saying, kami sedang dalam perjalanan." (HR. Ahmad $\left.{ }^{39}\right)$

Imam Bukhari bahkan meriwayatkan pesan-pesan Nabi beberapa hari menjelang wafatnya Rasulullah. Pesan dan wasiat ini merupakan hal-hal penting yang menyangkut uruan besar kaum muslimin. Kaum muslimin diwajibkan untuk memperhatikan hal tersebut

\footnotetext{
${ }^{36}$ Abu Abdillah Muhammad bin Yazid Al Qazawaini, Sunan Ibn Majjah, tahqiq: Muhammad Fu'ad Abdul Baqi, Mesir: Maktabah Ihya Al Kutub AL Arabiyyah, 1952, Jiild 2, hal. 1223

${ }^{37}$ Abu Abdillah Muhammad bin Sa'ad, Thabaqat al Kubra, tahqiq: Dr. Abdul Azis bin Abdullah as Salumi, Saudi Arabia: Maktabah As Shadiq, 1416, Jilid 1, hal. 556

${ }^{38}$ Ibn Khaldun, Tarikh, Jilid 2, hal. 52

${ }^{39}$ Abu Abdillah Ahmad bin Muhammad bin Hanbal, Musnad AL Imam Ahmad bin Hanbal, Tahqiq: Syuaib al Arnauth, Beirut: Mu'assasah Ar Risalah, 2001, Jilid 24, hal. 418
} 
dengan serius dan tidak melalaikannya. Pesan ini berisikan beberapa hal. Salah satunya beliau menyebutkan agar ummatnya memperlakukan utusan yang datang sebagaimana selama ini beliau memperlakukan mereka.

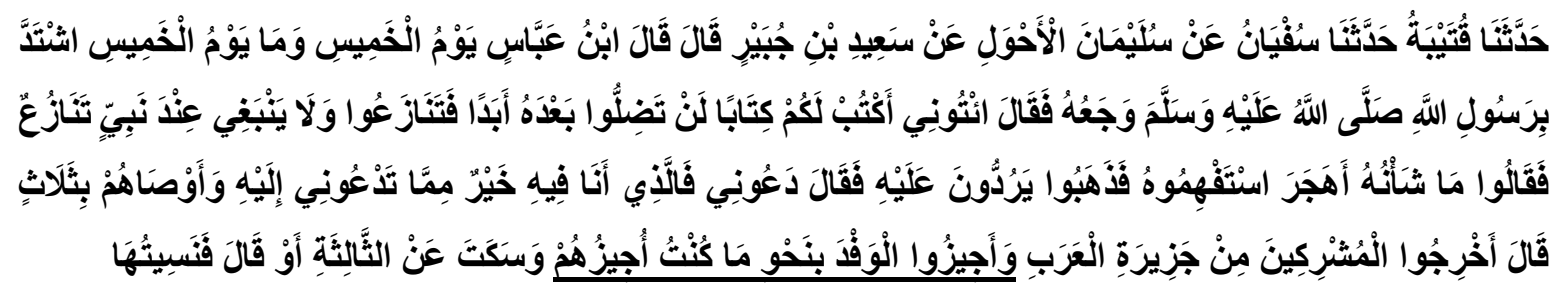

Telah menceritakan kepada kami Qutaibah(1) Telah menceritakan kepada kami Sufyan(2) dari Sulaiman Al Ahwal(3) dari Sa'id bin Jubair(4) dia berkata; Ibnu Abbas(5) berkata; "Ingatkan kalian hari kamis, dan ingatkan kalian hari kamis itu?" "Pada hari tersebut sakit Rasulullah shallallahu 'alaihi wasallam semakin parah, lalu beliau berkata: "Kemarilah, aku tuliskan untuk kalian sebuah surat, sehingga kalian tidak akan tersesat setelahnya selamanya." Namun mereka berselisih, padahal tidak pantas ada yang berselisih di dekat seorang Nabi. Mereka berkata; "Bagaimana keadaan beliau, apakah beliau mengigau? hendaknya kalian tanyakan kembali kepada beliau." lalu mereka pergi dan menyakannya kembali. Maka beliau bersabda: "Tinggalkan aku, keadaanku sekarang lebih baik dari pada apa yang kalian kira." Beliau mewasiatkan tiga hal, beliau bersabda: "Usirlah orang-orang musyrik dari Jazirah Arab, dan perlakukan utusan sebagaimana saya memperlakukan mereka." Tetapi Sa'id tidak menyebutkan wasiat yang ketiga, atau dia mengatakannya namun aku lupa." (HR. Al Bukhari) ${ }^{40}$

\section{F. Aspek Diplomasi melalui Surat}

Dalam menjalankan misi diplomasi, Negara-negara modern menggunakan sara surat menyurat untuk menyampaikan pesan-pesan kenegaraan secara resmi. Cara ini seringkali diambil dan menjadi salah satu pilihan dan strategi. Menarik untuk dicermati, bahwa suratsurat diplomasi yang dikirim oleh Rasulullah kepada kepala suku dan raja-raja serta para pemimpin mereka masih dapat terekam dengan baik dalam banyak riwayat. Hal itu menunjukan bahwa kuatnya tradisi literasi dan dokumentasi surat-surat tersebut dalam bentuk arsif. Dr. Hafidz al Karmi mengomentari hal ini dan menyatakan bahwa para sahabat telah melakukan tradisi administrasi berupa pencatatan ulang terhadap surat-surat yang dikirim kepada raja atau para penguasa. ${ }^{41}$ Hal tersebut didukung dengan banyaknya arsip yang sampai hari ini masih dapat dijumpai dan juga banyaknya riwayat yang secara rapih menceritakan hal tersebut. Muhammad Hamidullah di dalam kitabnya Majmu'ah al Watsa'iq As

\footnotetext{
${ }^{40}$ Muhammad bin Isma'il Abu Abdillah AL Bukhari al Ju'fi, Sahih Al Bukhari, Tahqiq: Muhammad Zahir bin Nashir, Riyad: Dar Tauqun Najah, 1422m Jilid 4, hal. 69

${ }^{41}$ Hafidz Ahmad 'Ajjaj al Karmi, Al Idarah fi 'Ashri al Rasul, hal.
} 
siyasiyyah li 'Ahdi An Nabi wa al Khilafah al Rasyidah mencatat sejumlah surat, dokumen dan perjanjian-perjanjian yang berjumlah lebih dari 250 dokumen. ${ }^{42}$

Dalam mengirimkan suratnya Nabi menyesuaikan dengan tujuan sesuatu dikirimkan ada surat yang bertujuan untuk menerangkan hukum-hukum Islam seperti surat yang diberikan kepada kaisar Romawi dan raja najasyi serta Al Muqauqis. Pada surat itu disebutkan kalimat; ..."Aku menyuruh Anda kepada Allah Semata....". 43 Ada pula suratsurat yang berisi seruan kepada ahlu dzimmah kepada Islam seperti kalimat;

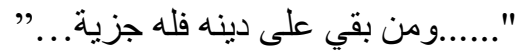

(...barangsiapa tetap berada pada agamanya maka dia wajib membayar jizyah...)

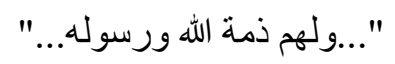

(...dan bagi mereka jaminan Allah dan rasulnya..) Seperti surat yang dikirimkan kepada Adzrah dan Jarba'. (Al Halabi, As Sirah, jilid 3, hal. 160) ${ }^{44}$. Sebagiannya lagi menjelaskan tentang hukum-hukum syari'at sebagaimana surat Nabi kepada Amr bin Hazm, gubernur beliau di Bahrain. ${ }^{45}$

Nabi selalu membuka atau memulai surat beliau dengan kalimat;

$$
\text { من محمد رسول الله }
$$

(..”dari Muhammad utusan Allah...”.)

Jadi nabi memulai surat dengan nama asli, gelar, kemudian nama dan gelar orang yang dikirimi surat. Al Qalqasyandi menjelaskan bahwa Bangsa non-Arab ketika menulis surat biasanya mereka memulainya dengan nama raja mereka sedangkan Rasulullah menulis surat dengan memulainya dengan nama beliau. Demikian pula para sahabat juga mengirim surat dan memulainya dengan nama mereka seperti Rasulullah berkirim surat kepada mereka. ${ }^{46}$

Dilihat dari surat-surat diplomatik Rasulullah, beliau menyeru para raja dengan menggunakan kata tunggal (mufrad), bukan dalam bentuk jamak (prular). Beliau menulis;

$$
\text { إنى احمد الله إليك }
$$

\footnotetext{
${ }^{42}$ Muhammad Hamidullah, Majmu'ah al Watsa'iq As siyasiyyah li 'Ahdi An Nabi wa al Khilafah al Rasyidah, Beirut: Dar An Nafa'is, 1987, hal. 1-300

${ }^{43}$ Ibid, hal. 109

${ }^{44}$ Abil Abbas Ahmad Al Qalqasyandi, Shabhul A'sya, Mesir : Dar Al Kutub Al Hudaywiyyah, 1915, Jilid 3, hal. 160

${ }^{45}$ Ibn Hisyam, As Sirah, Jilid. 2, hal. 294

${ }^{46}$ Abil Abbas Ahmad Al Qalqasyandi, Shabhul A'sya, Jilid 6, hal. 329
} 
(...”Aku memanjatkan pujian kepada Allah, seraya menyerukan kepada anda...”) ${ }^{47}$. Atau dengan kalimat;

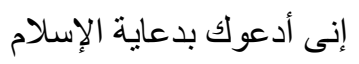

(...Aku menyeru anda dengan seruan Islam.... $)^{48}$

Surat-surat Nabi menyeru raja atau pemimpin dengan gelar-gelar mereka seperti surat kepada Kaisar Romawi dan Raja Persia; عظيم الوم (Kaisar Romawi) dan عظيم فارش (Kaisar Persia). Adapun kepada Raja Muqouqis beliau menggunakan istilah; صاحب مصر (Raja Mesir), dan kepada Raja Najasy dengan sebutan; ملك الحبشة (Raja Habasyah). ${ }^{49}$

Sumber-sumber yang ada menurut Dr. Hafidz al Karmi menyebutkan tidak adanya penyimpanan salinan naskah. Hanya saja dalam perjanjian Hudaibiyah Nabi menulis dua naskah. Naskah pertama dimiliki Nabi dan naskah yang kedua dibawa oleh Suhail bin Amr. ${ }^{50}$

Abdullah bin Amr menuturkan bahwa surat diplomasi pertama yang ditulis pada masa Rasulullah adalah surat beliau kepada penduduk Makkah. Dari sini sangat memungkinkan Abdullah menyalin dari Naskah Nabi yang disimpan oleh para sahabat. Artinya ada suatu isyarat adanya penyimpanan pengarsipan tersebut. Adapula naskah yang dikirmkan kepada beberapa pihak. Naskah naskah itu disimpan oleh beberapa sahabat diantaranya Ibnu Abbas, Abu Bakar bin Hazm dan Urwah bin Az Zubair. Hal itu kemudian diteruskan pada masa Khalifah Ar Rasyidah seperti Umar Ibn Khattab. Sehinga menurut Al Baladzuri bahwa sepermpat abad setelah wafatnya Rasulullah di Madinah terdapat Bayt al Qarathis (gudang kertas) yang menempel dengan rumah sahabat Utsman bin Affan (Al Baladzuri, Ansab, Jilid 1, hal. 22)

Untuk memastikan keaslian surat, Nabi tidak mengirim surat kecuali telah bersetempel. Untuk itu Nabi memerintahkan kepada para sahabat untuk tidak membuat setempel yang sama. Imam An Nawai dalam Fathul Bari menjelaskan bahwa Hal demi menjaga otentitas surat karena akan menjadi kekacauan apa bila tidak ada larangan mengenai

\footnotetext{
${ }^{47}$ Muhammad Hamidullah, Majmu'ah al Watsa'iq As siyasiyyah li 'Ahdi An Nabi wa al Khilafah al Rasyidah, hal. 100

${ }^{48}$ Ibid, hal. 103-104

${ }^{49}$ Ibid., hal. 100

${ }^{50}$ Al Qawidi, Al Magazi, Juz 2, hal. 612
} 
hal ini jika terdapat setempel serupa. ${ }^{51} \mathrm{Hal}$ ini sebagaiman diriwayatkan oleh sahabat Anas bin Malik dalam catatan Imam Al Bukhari.

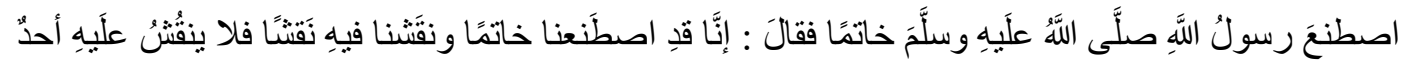

Berkata Anas bin Malik; Rasulullah telah membuat setempel. Lalu beliau bersabda; "Kam telah membuat setempel dan telah kami ukirkan tulisan padanya. Maka janganlah seseorang membuat ukiran yang sama." (HR. Ahmad ${ }^{52}$ )

Secara khusus, urusan persetempelan ini diserahkan oleh Nabi kepada salah seorang sahabatnya yang bernama Mu'aqib bin Abi Fathimah sebagaimana dijelaskan oleh Imam Ibn Abdil Barr ketika menulis biografi sahabat Mu'aqib. ${ }^{53}$

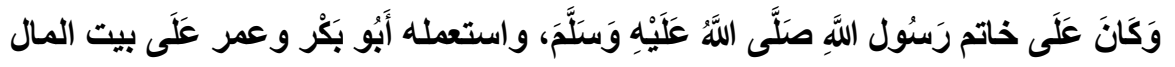

(Dialah yang menjaga stempel Rasulullah shalallahu 'alaihi wasallam dan digunakan pula pada masa Abu Bakar dan Umar pada Baitul Mall.)

Selain berupa surat-surat diplomatik yang berisikan ajakan, pesan, dan dakwah, maka surat-surat diplomatik juga berisikan bentuk-bentuk perjanjian. Seperti perjanjian Hudaibiyah yang sangat masyhur sebagai tonggak kemenangan kaum muslimin untuk Fathhu al Makkah. Nabi juga mengikat perjanjian dengan duta dari Hamadzan, An Nakh', Kalb, Tsaqif, Adzrah, Jarba' dan lain-lain. Secara umum isi perjanjian banyak kemiripan, namun memiliki beberapa kesepakan yang berbeda-beda sesuai dengan kondisinya. Perjanjian tersebut ditulis dengan kalimat-kalimat yang padat dan tidak ditulis dengan kalimat sajak. Dalam kesepakatan Nabi menuliskan Nama tanpa imbuhan gelar apapun. Namun dalam perjannjian tersebut Nabi menyebutkan sifat sebagai Rasul Allah dan Nabinya, dengan maksud mengingatkan hakekat tugas beliau, sekaligus mengukuhkan maknanya ke dalam hati yang menerima. ${ }^{54}$ Berikut ini contoh surat perjanjian dengan Adzrah;

\footnotetext{
${ }^{51}$ Ahmad Abdurrahman Al Bana, Fathu Rabbani li Tartib Musnad al Imam Ahamd As Syaibani, Beirut: Dar Ihya al Turats al Islamy, Jilid 7, hal. 258

${ }^{52}$ Abu Abdillah Ahmad bin Muhammad bin Hanbal, Musnad AL Imam Ahmad bin Hanbal, Jilid. 49, hal. 19. Lihat pula, Abu 'Aunah Ya'qub bin Ishaq bin Ibrahim an Naisabury, Mustakhraj Abi 'Aunah, Tahqiq: Aiman bin Arif ad Dimasqi, Beirut: Dar al Ma’arif, 1998, Jilid 5, hal. 263

${ }^{53}$ Ibn Abdil Barr, Al Isti'ab fi Ma'rifatil Ashab, Tahqiq: Ali Muhammad Bajawi, Beirut: Dar Al Jiil, 1992, Jilid 4, hal. 1479

${ }^{54}$ Hafidz Ahmad 'Ajjaj al Karmi, Al Idarah fi 'Ashri al Rasul, hal. 138. mengutip. Mahmud, Al Mu'ahadat fi al Islam, hal. 37
} 


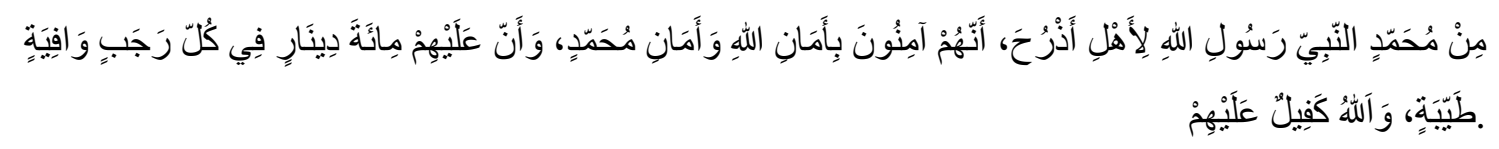

Berbagai bentuk surat perjanjian, kesepakatan, dan lainnya menunjukkan betapa cerdasnya Rasulullah dalam hal berdiplomasi. Beliau telah meletakkan contoh contoh diplomasi secara konkrit dan dikagumi oleh lawan-lawannya. Jika dilihat, maka selutuh diplomasi yang dilakukan oleh Rasulullah bertumpu pada kemaslahatan masyarakat Islam.

\section{PENUTUP DAN KESIMPULAN}

Dalam kajian keislaman, sebenarnya Islam sangat kaya akan literatur diplomasi yang termuat dalam kajian hubungan internasional. Para ulama telah membahasnya dalam kajian as siyar wa al jihad (perdamaian dan peperangan). Sangat banyak para ahli fiqih yang telah mengkompilasikannya dan dikemudian hari menjadi panduan dalam kaitannya dengan diplomasi. Para ulama mencatata bahwa ulama yang pertama kali mengkompilasikan pembahasan ini adalah Al Imam Abu Hanifah. Kajian Imam Abu Hanifah ini kemudian diteruskan dikembangkan oleh para murid-muridnya diantaranya Al Imam Muhammad bin Hasan As Syaibani. Bukunya yang berjudul As Siyar as Saghir dan As Siyar al Kabir menjadi buku sistematis pertama setelah karya Imam Abu Hanifah. Karya Imam As Syaibani ini kemudian diberikan ulasan dan catatan oleh Al Imam Al Syarakhsi, seorang Ahli Fikih terbesar Mazhab Hanafi dengan judul Syarah kitab As Siyar al Kabir.

Kajian kajian berikutnya terus berkembang dan menjelaskan tentang hubungan diplomasi terutama pada bab siyar wa jihad diatas. Tentu saja kajian tersebut adalah hasil penelaahan terhadap hadits dan riwayat dari para sahabat geneasi salaf as shalih tentang aktivitas diplomasi yang banyak terekam pada diri mereka. Kajian-kajian ini menunjukkan besarnya perhatian Islam tentang persoalan diplomasi. Selain itu, sebagaimana yang diulas sebelumnya, diplomasi dalam Islam jauh lebih modern dan berkembang lebih bermartabat jika dibandingkan dengan diplomasi yang berkembang di Barat sampai dengan Abad Modern dan hari ini. Dengan demikian Islam adalah pioner "Diplomasi Bersih" meminjam istilah Prof. Dr. Tulus Warsito. Kajian Afzal Iqbal dan para ulama sebelumnya telah menunjukkan 
bahwa Nabi telah membangun kaidah-kaidah diplomasi yang kuat sehingga menjadi dasar bagi Negara Islam atau para diplomat muslim untuk mempedomaninya. Wahbah Zuhaili guru besar hukum Islam di universitas damaskus menyebutkan sekitar 7 basis etika yang harus diperhatikan oleh pemerintahan muslim dalam hubungan antar negara atau internasional yaitu: 1) memelihara kedaulatan Negara. 2) memperkuat kerjasama antar negara muslim. 3) memelihara perdamaian dunia. 4) memelihara kemuliaan hak-hak asasi manusia, keadilan, kebebasan, dan persamaan kerjasama antar negara dan mendakwahkan islam. 5) menjaga Islam dari berbagai serangan dan hujatan. ${ }^{55}$

Adapun Muhammad Dasuki, guru besar hukum internasional dari Universitas alazhar menyebutkan 5 basis etika dalam hubungan internasional persamaan manusia perdamaian sebagai prinsip dasar hubungan internasional perang sebagai jalan keluar untuk

memelihara perdamaian keadilan dan peri kemanusiaan menghormati perjanjian. ${ }^{56}$ Zahid bin Abdul Karim Zaidan guru besar dan dekan Institut peradilan King Saud University Riyadh menyebutkan 6 basis etika dalam hubungan internasional; kesatuan kemanusiaan, toleran toleransi, kebebasan keadilan interaksi Setimpal. ${ }^{57}$

\section{DAFTAR PUSTAKA}

1. Abdu Syafi Muhammad Abdul Latif, As Sirah An Nabawiyah wa At Tarikh Al Islâmiy, Mesir: Dar As Salam, 1428

2. Abil Abbas Ahmad Al Qalqasyandi, Shabhul A'sya, Mesir : Dar Al Kutub Al Hudaywiyyah, 1915

3. Abu 'Aunah Ya'qub bin Ishaq bin Ibrahim an Naisabury, Mustakhraj Abi 'Aunah, Tahqiq: Aiman bin Arif ad Dimasqi, Beirut: Dar al Ma'arif, 1998

4. Abu Abdillah Ahmad bin Muhammad bin Hanbal, Musnad AL Imam Ahmad bin Hanbal, Tahqiq: Syuaib al Arnauth, Beirut: Mu'assasah Ar Risalah, 2001

5. Abu Abdillah Muhammad bin Sa'ad, Thabaqat al Kubra, tahqiq: Dr. Abdul Azis bin Abdullah as Salumi, Saudi Arabia: Maktabah As Shadiq, 1416

${ }^{55}$ Wahbah Az Zuhaili, Al Fiqhu al Islami wa Adillatuhhu, Damskus: Thiba'ah Dar al Fikr, 1985, Jilid 8, hal. 6406

${ }^{56}$ Muhammad AD dasuqi, Usulul Alaqad Ad Duwaliyyah, h. 599-603)

${ }^{57}$ Zaid bin Abdul Karim Az Zaid, Muqaddimah fi Qanun ad Duwali al Insani fi al Islam, halaman 15 sampai 16) 
6. Abu Abdillah Muhammad bin Yazid Al Qazawaini, Sunan Ibn Majjah, tahqiq: Muhammad Fu'ad Abdul Baqi, Mesir: Maktabah Ihya Al Kutub AL Arabiyyah, 1952

7. Abu Amru Khalifah bin Khayyat, Târikh Khalifah bin Khayyath, Tahqiq: Dr. Akram Dhiya’ Al Umari, Beirut: Dar Al Qalam, 1397

8. Afzal Iqbal, Diplomasi Islam, Jakarta: Pustaka Al Kautsar: 2007

9. Ahmad Abdurrahman Al Bana, Fathu Rabbani li Tartib Musnad al Imam Ahamd As Syaibani, Beirut: Dar Ihya al Turats al Islamy,

10. Ali Muhammad Ashalabi, Sirah Amirul Mukminin Umar bin Khattab; Syakhsiyatuhu wa 'Ashruhu, Mesir: Mu'assasah Iqra: 2005

11. Ernest Satow, A Guide to Diplomacy Praktic, The Library of California,

12. Hafidz Ahmad 'Ajjaj al Karmi dalam bukunya Al Idarah fi 'Ashri al Rasul, Mesir: Dar As salam IIIT, 2000

13. Harold Nocolson, Diplomacy, London: Oxford University Toronto, 1939, hlm. 14

14. https://www.oxfordlearnersdictionaries.com/definition/english/diplomacy?q=diplo macy

15. Ibn Abdil Barr, Al Isti'ab fi Ma'rifatil Ashab, Tahqiq: Ali Muhammad Bajawi, Beirut: Dar Al Jiil, 1992

16. Ibnu Hajar al Atsqalani, Al Ishabah fî Tamayyiz Al Shahabah, Tahqiq. Syaikh Adil Ahmad Abdul Maujud, et.all, Lebanon: Dar Al Kutub al Ilmiyyah, 1995

17. Ibnu Qayyim Al Jauziyah, Zaâdul Ma'ad min Hadyi Khairil 'Ibad, Beirut: Mu'assasah Ar Risalah, 1994

18. Ichwan Fauzi, Etika Muslim, Penerbit, Wisdom Science Sea,

19. Mr. Ag. Pringgodigdo, Ensiklopedia Umum, Yogyakata: Penerbit Kanisius, 1973

20. Muhammad Asyraf bin Amir bin Ali bin Hidr Al Adzim Al Abadi, 'Aunul Ma'bûd Syarah Sunan Abi Dâwûd, Beirut: Darul Kutub Al Ilmiyyah, 1415

21. Muhammad bin Hibban bin Ahmad bin Hibban, Sahih Ibn Hibban bi at Tartib al Hibban, Tahqiq: Syuaib al Arnauth, Beirut: Mu'assasah Ar Risalah, 1993

22. Muhammad bin Isma'il Abu Abdillah AL Bukhari al Ju'fi, Sahih Al Bukhari, Tahqiq: Muhammad Zahir bin Nashir, Riyad: Dar Tauqun Najah, 1422

23. Muhammad bin Jarir bin Katsir At Thabari, Tarikh Ar Rusul wa Al Muluk, Beirut: Dar At Turats, 1387

24. Muhammad Habas, Al Islam wa Al Diplomasiyyah; Qira'ah fi al Qim al Diplumasiyyah fì al Islâm, Arabiya: Aspir Printing Press, 2013

25. Muhammad Hamidullah, Majmu'ah al Watsa'iq As siyasiyyah li 'Ahdi An Nabi wa al Khilafah al Rasyidah, Beirut: Dar An Nafa'is, 1987

26. Muhammad Hamidullah, The Muslim Conduct of State, Kuala Lumpur: Islamic Book Trust, 2012

27. Musa Syahhin Al Asyin, Fathul Mun’im Syarah Sahih Muslim, Mesir: Dar Al Suruq, 2002

28. PBB, Vienna Convention on Diplomatic Relations 1961, Copy Rigt United Nation, 2005, hal. 8

29. Sami bin Abdullah Al Malghuts, Athlas At Tarikhi li as Sirah An Nabawiyah, Riyadh: Maktabah Al Ubaikan, 2004

30. Sulaiman Al Ruhaili, As Sifarât AL Islâmiyyah ilâ Bilad Bizantiyyah, Riyadh: Maktabah At Taubah, 1414 
31. Tulus Warsito dan Surwandono, Jurnal Tauqifiyah, DIPLOMASI BERSIH" DALAM PERSPEKTIF ISLAM, Vol. 16, No. 2, Desember 2015

32. Umar Suryadi Bakri, Dasar-dasar Hubungan Internasional, Depok: Penerbit Kencana, 2017

33. Wahbah Az Zuhaili, Al Fiqhu al Islami wa Adillatuhhu, Damskus: Thiba'ah Dar al Fikr, 1985 